\title{
In tetl, in cuahuitl. Los sistemas jurídicos nahuas prehispánicos ante el adulterio
}

\author{
In tetl, in cuahuitl. Pre-hispanic Nahuatl Juridical Systems \\ in Relation to Adultery
}

Miriam López Hernández*

INSTITUTO DE INVESTIGACIONES ESTÉTICAS, UNAM, mirlop@yahoo.com

El artículo estudia las penas contra el adulterio en los sistemas jurídicos de los antiguos nahuas. Analiza los factores en el sistema de aplicación de los castigos de acuerdo al tipo de evidencia, a las circunstancias, a la clase social y al género. Transgredían el orden social aquellas mujeres casadas que tenían relaciones sexuales con un varón que no fuera su esposo; en contraste, los hombres violaban la ley cuando tenían relaciones con la esposa de otro.

PaLABRas Clave: adulterio, nahuas, leyes, castigos, prehispánico.

This article studies the sanctions imposed on adultery in the juridical systems of the ancient Nahuatls, analyzing the factors involved in the system of the application of punishments in relation to the following factors: type of evidence, circumstances, social class, and gender. A married woman who had sexual relations with a man other than her husband was perceived to have transgressed the social order; in contrast, a man who had sexual relations with another man's wife was accused of violating the law.

KeYwords: adultery, Nahuatls, laws, punishment, pre-Hispanic.

Fecha de recepción del artículo: 11 de marzo de 2014 / Fecha de aprobación: 29 de septiembre de 2014 / Fecha de recepción de la versión final: 26 de mayo de 2015

\section{INTRODUCCIÓN}

I

os cronistas muestran que existieron varios sistemas jurídicos entre los nahuas y otros pueblos precolombinos. Las normatividades en estas sociedades buscaban regular la conducta y

*La revisión y corrección de este artículo fue posible gracias a la beca posdoctoral que me otorgó la Coordinación de Humanidades de la UNAM, en el marco del programa de Becas Posdoctorales en la UNAM. Agradezco los útiles comentarios y sugerencias de los dos dictaminadores anónimos del presente trabajo. 
especificaban los castigos de acuerdo con la falta cometida y según el infractor. Puede decirse de manera general que estos ordenamientos tuvieron dos orígenes. Probablemente derivaron de antiguas costumbres que con el paso del tiempo fueron elevadas al nivel de leyes explícitas y estrictamente aplicadas que conformaron los códigos que definieron los aparatos jurídicos nahuas como poderes institucionalizados. ${ }^{1}$

\section{Otra fuente fue el tratamiento caso por caso:}

los reyes y los jueces [...] al castigar algún delito o al fallar en algún negocio, sentaban una especie de jurisprudencia, pues el castigo en materia penal se tenía como ejemplo, que era repetido más tarde en idénticas circunstancias, y el fallo en cuestiones civiles como una ley que se observaba fielmente en posteriores ocasiones. ${ }^{2}$

En los primeros reportes de leyes nahuas ${ }^{3}$ encontramos regulaciones en torno a la cacería, el respeto a los bosques, a los espacios reservados para esta actividad y al derecho entre los cazadores sobre las presas obtenidas. Asimismo, se hace mención del adulterio como único delito adicional a aquellos relacionados con la actividad económica dominante, lo cual le otorga un lugar fundamental en el sistema jurídico desde sus inicios. ${ }^{4}$

${ }^{1}$ Alfredo López Austin, La Constitución real de México-Tenochtitlan (México: UnAM, 1961), 83; Jerome Offner, Law and politics in aztec Texcoco (Cambridge: Cambridge University Press, 1983), 83-86; Carlos Brokmann, La justicia en el México prehispánico (México: Suprema Corte de Justicia de la Nación, 2010), 59.

${ }^{2}$ Lucio Mendieta y Núñez, "El derecho mexicano antes de la conquista”, Ethnos i (812) (1922): 169.

${ }^{3}$ Jerome Offner, Law and politics in aztec Texcoco, 245, define el concepto de ley en la región de Texcoco a partir de cuatro características, las cuales considero pueden aplicarse a otras ciudades nahuas: a) la ley era el mandato del gobernante; b) era una fuerza peligrosa e inexorable, especialmente cuando uno presentaba una acusación o se asociaba con una autoridad; c) la ley debía aplicarse de manera escrupulosa y consistente; d) idealmente, debía beneficiar a toda la sociedad.

${ }^{4}$ Fernando Alva Ixtlilxochitl, Historia de la nación chichimeca, en Obras Históricas, tomo II, edición, estudio introductorio y un apéndice documental por Edmundo O’Gorman (México: Instituto Mexiquense de Cultura, IIH, unAM, 1997, 24). 
Se consideraba adulterio al yacimiento de una mujer casada ${ }^{5}$ con una persona distinta de su cónyuge, siendo éste casado o soltero. ${ }^{6}$ A diferencia de esta concepción, a los varones se les juzgaba cuando se habían amancebado con la mujer de otro: una mujer casada. ${ }^{7}$ Si tenía relaciones con una mujer soltera no se consideraba transgresión.

En su definición, al incluir sólo a las mujeres casadas lo que se buscaba era asegurar la paternidad. ${ }^{8}$ Paralelamente, se les juzgaba a

${ }^{5}$ Llamada cibuatlantli, la cual había sido pedida como mujer, es decir, solicitada en matrimonio.

${ }^{6}$ Diferentes registros indican que los jóvenes no cumplían con el ideal de moderación sexual que se les exigía y, por tanto, eran castigados de diferentes maneras. Si un joven era descubierto cortejando o teniendo relaciones sexuales "le daban garrote, o le asaban vivo o le asaeteaban" (Fray Bernardino de Sahagún, Historia general de las cosas de Nueva España, Colección Cien de México, estudio introductorio, paleografía, glosario y notas de Alfredo López Austin y Josefina García Quintana, tomo I (México: Conaculta, 2002), 339. Cuando el tlatoani se enteraba que alguien se habían amancebado, directamente ordenaba su ejecución (Ibid., II, 759). Igualmente, se menciona, en otros casos, que lo apaleaban, le chamuscaban la cabeza y lo arrojaban de la escuela, mientras que a la muchacha también la castigaban con la expulsión y "nunca más había de danzar ni cantar ni estar con las otras". En algunas ocasiones sólo los casaban (ibid., II, 217; Alfredo López Austin, Educación mexica: antología de documentos sahaguntinos, selección, paleografía, traducción, introducción, notas y glosario de Alfredo López Austin (México: IIA, UNAM, 1985), 131.

${ }^{7}$ Cabe mencionar que las concubinas de otros hombres eran, en apariencia, caza permitida. Sin embargo, contamos con el dato que indica que si una concubina tenía relaciones con alguien aparte del hombre con quien estaba relacionada, ella era entregada a los jóvenes para que se aprovecharan de ella (violación tumultuaria), aparentemente el hombre envuelto en esto no recibía castigo (Relación de Zempoala y su partido en Tlalocan, vol. 3, 1949, 31, 36).

${ }^{8}$ Sobre el matrimonio nahua léase: Fray Toribio de Benavente Motolinía, El libro perdido, dir. Edmundo O'Gorman (México: Conaculta, 1989), 540-544; Memoriales o Libro de las cosas de la Nueva España y de los naturales de ella, Serie de Historiadores y Cronistas de Indias 2, ed. Edmundo O'Gorman (México: IIH, unAM, 1971), 313-334, 319-320; Códice Mendoza, en Antigüedades de México, vol. I, recopilador Lord Kingsborough, palabras preliminares de Antonio Ortiz Mena, prólogo de Agustín Yáńez, estudio e interpretación de José Corona Núñez, LXII, lám. 61r (México: SHCP, 1964); Fray Bartolomé de Las Casas, Apologética historia sumaria, tomo II, edición, estudio preliminar, apéndices e índice de materias por Edmundo O'Gorman (México, IIH, UNAM, 1967), 411-415; Fray Gerónimo de Mendieta, Historia eclesiástica indiana, Colección Cien de México, tomo I, noticias del autor y de la obra por Joaquín García Icazbalceta, estudio preliminar de Antonio Rubial García (México: Conaculta, 2002), 245-247; Fray Bernardino de Sahagún, Florentine Codex. General History of the Things of New Spain, Fray Bernardino de Sahagún, traducido del náhuatl al inglés, notas e ilustraciones por Charles E. Dibble y Arthur J. O. Anderson (Santa Fe: The School of American Research and The 
los adúlteros por violar los derechos de posesión de otros maridos, mientras que al varón que tuviera relaciones con una mujer soltera no se le condenaba, pues, no transgredía los derechos sexuales de otros hombres. ${ }^{9}$

Se perseguía de oficio, pues, se consideraba un delito en contra de la familia, del Estado y de la sociedad. Los criterios, ordenamientos y sanciones contra el adulterio son una muestra del sistema de protección que se tenía sobre los linajes. Se vigila, principalmente, la herencia; ${ }^{10}$ la sucesión en el gobierno; la legitimidad de los grupos de poder; $y$, como se señaló, la paternidad. El fin último es la cohesión y estabilidad social. ${ }^{11}$

University of UTAH, 1950-1982), lib. 2, 39-41, lib. 6, 127-133; Historia general, II, 581587; Fray Diego Durán, Historia de las Indias de Nueva España e islas de tierra firme, Colección Cien de México, tomo II (México: Conaculta, 2002), 66-67; Fray Juan de Torquemada, Monarquía Indiana, Serie de historiadores y cronistas de Indias 5, tomo IV, ed. Seminario para el estudio de fuentes de tradición indígena, coord. Miguel LeónPortilla (México: IIH, UNAM, 1975), 153-161.

${ }^{9}$ Éstas son leyes que tenían los indios de la Nueva España, Anábuac o México en Mitos e historias de los antiguos nahuas, Colección Cien de México, paleografía y traducciones de Rafael Tena (México: Conaculta, 2002), 101, 103; Mendieta, Historia eclesiástica indiana, I, 258; Torquemada, Monarquía Indiana, I, 229.

${ }^{10}$ Aunque ésta podía pasar a través de ambos sexos, tenía una fuerte inclinación masculina.

${ }^{11}$ Los pipiltin (nobles) eran quienes podían tener más de una mujer, pero sólo una era considerada la principal y esposa. Juan Cano, tercer esposo de Isabel Moctezuma, hija de Moctezuma II, explica la situación de la siguiente manera: "Fue costumbre usada y guardada entre los mexicanos, que las mujeres legítimas que tomaban, era de la manera que agora se dirá [...] tomaban la halda delantera de la camisa de la novia, e atábanla a la manta de algodón que tenía cubierto el novio [...] E los que sin esta ceremonia se casan no son habidos por matrimonio, ni los hijos que proceden por legítimos, ni heredan" (William H. Prescott, "Diálogo de Oviedo con Don Thoan Cano, sacado de la Historia de las Indias Ms., lib. XXXIII, cap. XLIv", en Historia de la conquista de México, tomo II, trad. J. Navarro (París: Librería de Ch. Bouret, 1877), 367.

Idealmente, los hijos de la mujer principal eran los herederos del padre, pero tenemos casos donde hijos de concubinas fueron tlatoque. Por ejemplo Itzcoatl, cuarto gobernante mexica, fue hijo de Acamapichtli, primer tlatoani mexica, y de una concubina tepaneca de baja estirpe. Itzcoatl fue escogido como heredero al trono debido a la coyuntura política que se vivía en la ciudad. Chimalpopoca, su antecesor, había sido asesinado por una fracción de los tepanecas. Su ascendencia y su experiencia como tlacochcalcatl, el puesto militar de más alto rango, le permitieron ser tlatoani. Decisión muy acertada, pues, fue él quien impulsó el poderío mexica y puede considerársele el fundador del imperio. 
Figura I. Códice Mapa Quinatzin, lám. 3
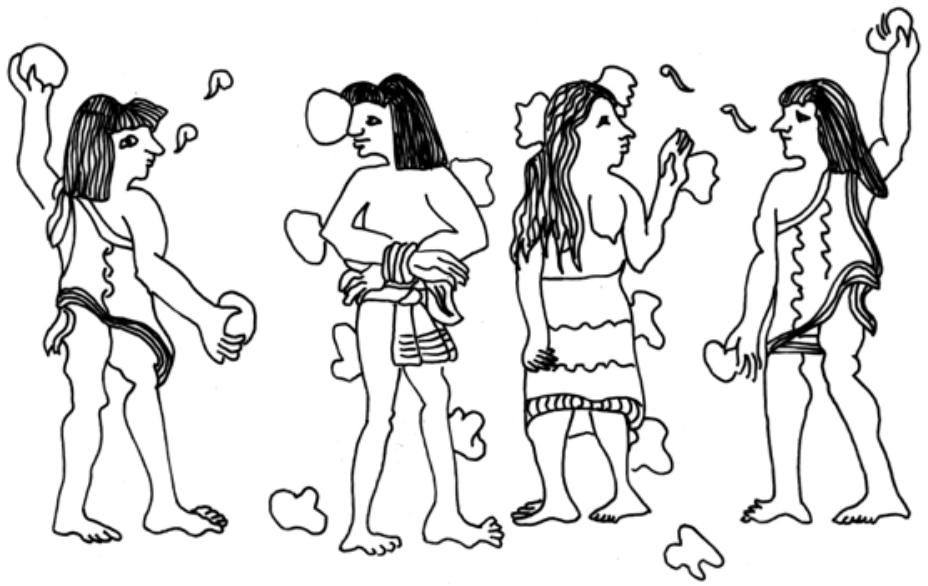

Dibujo de Miriam López.

El término para referirse a adulterio era tetlaximaliztli ${ }^{12}$ cuya raíz xima apunta a la acción de cortar, considero que en el sentido de dividir el matrimonio. A estos transgresores los llamaban tetlaximani, tetlaxinqui o tetlanxinqui y tepanyani (figura 1). ${ }^{13}$ El padre Jacinto de la Serna nos proporciona otros vocablos en los cuales se destaca su vínculo con la diosa Tlazolteotl. ${ }^{14}$ Indica que los muertos por este delito eran llamados tlazolteomiqui. Asimismo, señala el término tlazolteotlahpaliuhqui ${ }^{15}$ aplicado a aquellos que sufrían compresión de cabeza con una losa, el cual proviene de tlahpaliuhcatl palabra que designaba a los jóvenes varones casados. En tanto, a

${ }^{12}$ Fray Alonso de Molina, Vocabulario en lengua castellana y mexicana y mexicana y castellana, sección náhuatl-español, estudio preliminar Miguel León-Portilla (México: Editorial Porrúa, 2004), fol. 110r.

${ }^{13}$ Ibid., sección español-náhuatl, fol. 5r; sección náhuatl-español, fols. 102r, 110r; Sahagún, Florentine Codex, lib. 4, 42, 45, 93.

${ }^{14}$ Jacinto de la Serna, Manual de ministros de indios para el conocimiento de sus idolatrias y extirpacion de ellas, en El alma encantada, Anales del Museo Nacional de México, presentación de Fernando Benítez, 347 (México: INI, FCE, 1987).

${ }^{15}$ Aunque él divide la palabra de la siguiente manera: tlazolteotlah paliuhqui. 
las mujeres adúlteras las llamaban tlazolteocihuatl ${ }^{16}$ de cihuatl, mujer. La raíz tlazolli que forma parte de estas palabras significa basura y era la metáfora de la transgresión sexual. ${ }^{17}$

Otros términos aplicados a estos transgresores que están relacionados con el tipo de castigo recibido eran cuatepitzic "cabeza quebrada" y cuatexamac "cabeza estrellada", ${ }^{18}$ de las raíces cuaitl "cabeza", pitzini "partirse, quebrarse" y xamani "estrellarse, romperse", tema que abordaré a continuación. ${ }^{19}$

\section{LA PENA POR ADULTERIO ${ }^{20}$}

Diferentes factores se tomaban en cuenta al aplicar los castigos contra esta transgresión. Por una parte, se consideraba el tipo de evidencia que incriminaba a los acusados y, por otra, la clase social de los mismos. Entre los macehualtin, si existía una prueba directa, es decir, si fueron descubiertos in fraganti, el castigo para ambos era - de acuerdo a la mayoría de los autores- la lapidación pública, realizada por una multitud, la cual a los pocos segundos dejaba los cuerpos de los condenados sepultados en piedras (figura 2). ${ }^{21}$ De acuerdo a los

${ }^{16}$ Molina (Vocabulario, sección español-náhuatl, fol. 87v; sección náhuatl-español, fol. $118 \mathrm{v}$ ) también lo traduce como mujer perversa.

${ }^{17}$ Alexis Wimmer, Diccionario de nábuatl clásico, en CEN (Compendio Enciclopédico del Náhuatl) (México: INAH, CD-ROM, 2004, entrada tlazolli.

${ }^{18}$ Sahagún, Florentine Codex, lib. 4, 93.

${ }^{19}$ Molina, Vocabulario, sección náhuatl-español, fols. 84r, 158v; Remi Siméon, Diccionario de la lengua nábuatl o mexicana, trad. Josefina Oliva (México: Siglo XXI editores, 2002), 397, 499, 762; Wimmer, Diccionario de náhuatl clásico, entradas pitzini, xamani.

${ }^{20} \mathrm{La}$ evidencia presentada en esta sección es un panorama general que se enfoca en los rasgos que parecen compartidos a partir de la información disponible. Las fuentes para el estudio de este tema refieren a las urbes y están escritas desde la visión de la clase dominante.

${ }^{21}$ Historia de los mexicanos por sus pinturas, en Mitos e historias de los antiguos nahuas, Colección Cien de México, paleografía y traducciones Rafael Tena, 91 (México: Conaculta, 2002); Luz María Mohar Betancourt, Códice Mapa Quinatzin. Justicia y derechos humanos en el México antiguo (México: CNDH, Ciesas, Miguel Ángel Porrúa, 2004), lám. 3, 287; Códice Mendoza, LXxII, lám. 71r; Códice Telleriano-Remensis, en Antigüedades de México, vol. I, recopilador Lord Kingsborough, palabras preliminares de Antonio Ortiz Mena, prólogo de Agustín Yánez, estudio e interpretación de José Corona Núñez (México: SHCP, 1964), xix, lám. 17r; Códice Vaticano Latino A 3738, en Antigüedades de México, vol. III, recopilador Lord Kingsborough, palabras preliminares de Antonio Ortiz 
Figura 2. Códice Mendoza, LXXII, lám. 71r.

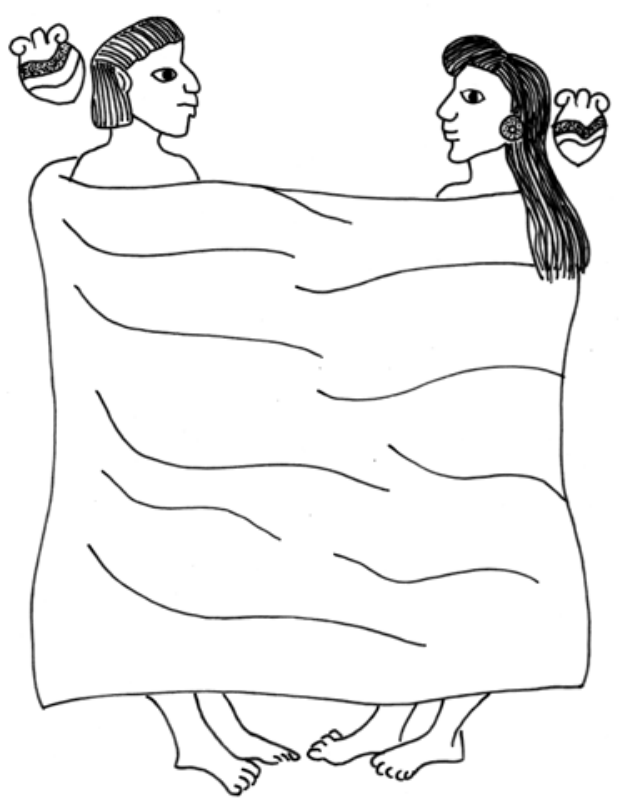

Dibujo de Miriam López.

códices Telleriano Remensis ${ }^{22}$ y Vaticano Latino A $3738^{23}$ a las mujeres previamente las estrangulaban.

Otros autores mencionan el castigo de quebrarles la cabeza con dos losas a los acusados. ${ }^{24}$ La utilización de piedras tiene dos fines: 1)

Mena, prólogo de Agustín Yáñez, estudio e interpretación de José Corona Núñez (México: SHCP, 1964), xxxvıII, lám. 25r; Mendieta, Historia eclesiástica indiana, I, 259; Sahagún, Florentine Codex, lib. 8, 42-43; Historia general, II, 758; Durán, Historia de las Indias, I, 266; II, 45; Fernando Alvarado Tezozomoc, Crónica Mexicana, notas de Manuel Orozco y Berra (México: Editorial Leyenda, 1944), 501; Fernando Alva Ixtlilxochitl, Sumaria relación, en Obras históricas, tomo I, ed. Edmundo O'Gorman, 385 (México, Instituto Mexiquense de Cultura, IIH, unAM, 1997); Torquemada, Monarquía Indiana, IV, 106.

${ }^{22}$ Códice Telleriano-Remensis, XIX, lám. 17r.

${ }^{23}$ Códice Vaticano Latino A 3738, xxxvıII, lám. 25r.

${ }^{24}$ Francisco Cervantes de Salazar, Crónica de la Nueva España, prólogo por Juan Miralles Ostos (México: Editorial Porrúa, 1985), 47-48; Juan Bautista de Pomar, Rela- 
matar al acusado (de una manera que impresionara a los espectadores); y 2) cubrir con infamia el cuerpo del delincuente.

En otros pasajes se menciona la pena de apaleamiento que recibían los adúlteros en caso de que la evidencia fuera igualmente directa. ${ }^{25}$ Es interesante que el difrasismo utilizado para referirse a "castigo" fuera "in tetl, in cuahuitl", en sentido literal "la piedra, el palo”, pero simbólicamente la idea es la sanción. Dichos objetos son justamente los que se utilizaban para aplicar las penas más severas ante este delito.

De acuerdo con Alva Ixtlilxochitl, si la evidencia era indirecta, es decir, si "de oídas" se supo del engańo, la pena era menos severa: ahorcamiento ${ }^{27}$ y el destierro para el caso de los guerreros. ${ }^{28}$

Dichas sentencias solían ejecutarse públicamente para que sirvieran como escarmiento y nadie se atreviera a hacer algo semejante. Generalmente se realizaba en la plaza, mercado o tianguis ${ }^{29}$ y después los cuerpos eran lanzados a los ríos ${ }^{30} \mathrm{o}$ sacados fuera de la ciudad para que los comieran las fieras ${ }^{31} \mathrm{o}$ arrastrados hasta un templo probablemente de Itztlacoliuhqui y echados en una barranca. ${ }^{32}$

Respecto a la identificación del templo, distintos documentos señalan que durante la duodécima trecena cuetzpalin, regida por

ción de Tezcoco en Poesía Nábuatl I, Romances de los Señores de la Nueva España, paleografía, versión, introducción, notas y apéndices de Ángel Ma. Garibay K. (México, IIH, UNAM, 2000), 183; Fernando Alva Ixtlilxochitl, Relación sucinta en forma de memorial de la historia de la Nueva España y sus señorios hasta el ingreso de los españoles, en Obras Históricas, tomo I, edición, estudio introductorio y un apéndice documental por Edmundo O'Gorman (México: Instituto Mexiquense de Cultura, IIH, unam, 1997), 405; Torquemada, Monarquia Indiana, Iv, 106.

${ }^{25}$ Mendieta, Historia eclesiástica indiana, I, 258; Sahagún, Historia general, II, 759; Torquemada, Monarquía Indiana, Iv, 106.

${ }^{26}$ Josefina García Quintana, "Exhortación de un padre a su hijo. Texto recogido por Andrés de Olmos”, en Estudios de cultura náhuatl, vol. 11, 1974, 155.

${ }^{27}$ Sumaria relación, 385.

${ }^{28}$ Historia de la nación chichimeca, 171.

${ }^{29}$ Mendieta, Historia eclesiástica indiana, I, 259; Sahagún, Historia general, II, 758759; Durán, Historia de las Indias, I, 266; Alva Ixtlilxochitl, Historia de la nación chichimeca, 164-165; Torquemada, Monarquía indiana, IV, 106.

${ }^{30}$ Sahagún, Florentine Codex, lib. 4, 45; Durán, Historia de las Indias, I, 266.

${ }^{31}$ Durán, Historia de las Indias, II, 45.

${ }^{32}$ Alva Ixtlilxochitl, Historia de la nación chichimeca, 164-165, 172. 
Figura 3. Códice Borbónico, lám. 12
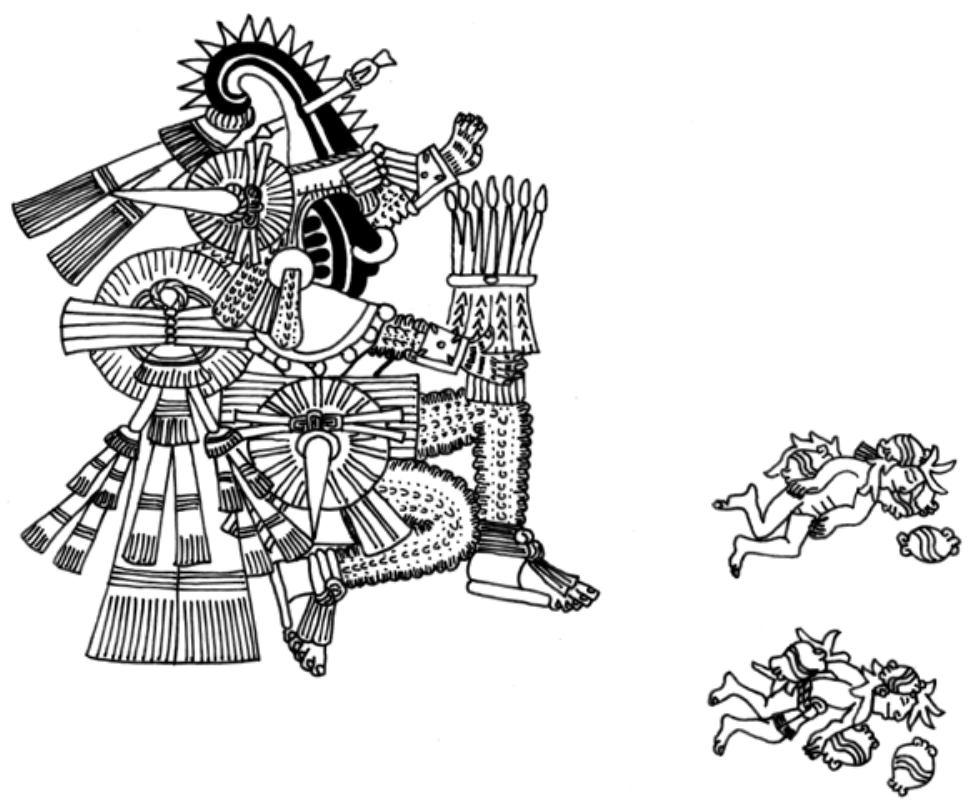

Dibujo de Miriam López.

Itztlacoliuhqui, se llevaban a cabo ejecuciones por adulterio. Así frente a la imagen de este dios en los códices Borbónico, ${ }^{33}$ Telleriano Remensis ${ }^{34}$ y Vaticano Latino A $3738^{35}$ aparece lapidada una pareja. Igualmente, este aspecto de Tezcatlipoca está claramente vinculado con las transgresiones sexuales (figura 3). ${ }^{36}$

${ }^{33}$ Códice Borbónico, Manuscrito mexicano de la biblioteca del Palais Bourbon: libro adivinatorio y ritual ilustrado, edición facsimilar, descripción, historia y exposición del Códice Borbónico por Francisco del Paso y Troncoso, con un comentario explicativo por E. T. Hamy (México: Siglo XXI editores, 1993), lám. 12.

${ }^{34}$ Códice Telleriano-Remensis, XviII, lám. 16v, XIx, lám. 17r.

${ }^{35}$ Códice Vaticano Latino A 3738, xxxvis, lám. 24v, xxxvıII, lám. 25r.

${ }^{36} \mathrm{El}$ tema del adulterio y el discurso religioso merece un estudio aparte. Véase, mientras tanto, Miriam López Hernández, "Las transgresiones sexuales entre los nahuas prehispánicos” (Tesis de Maestría en Antropología, FFL, IIA, UNAM, 2009), 165-172. 
ESQUEMA I*

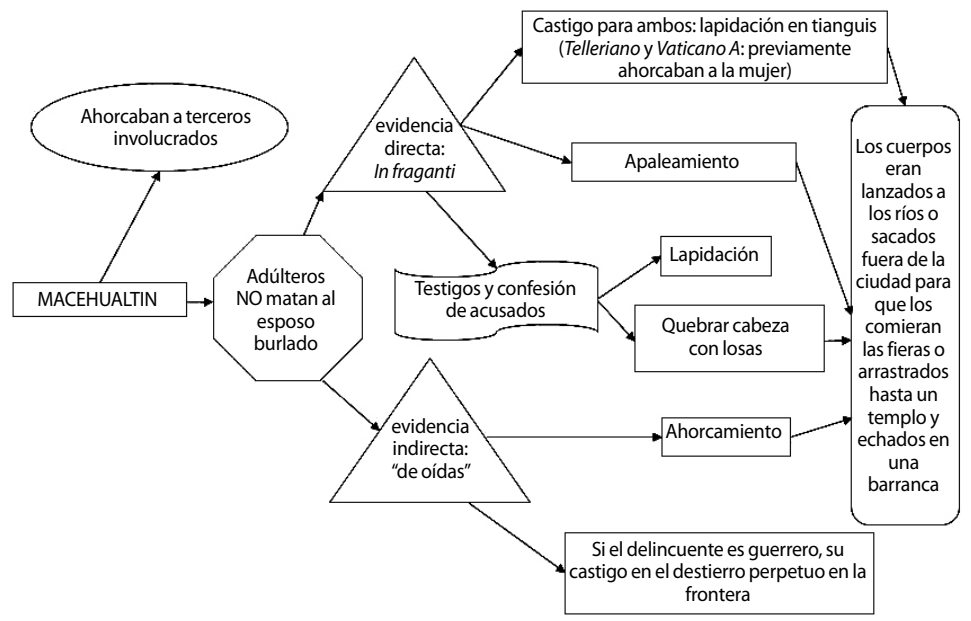

* Esquemas basados en las tablas 6.12 y 6.13 de Offner, Law and politics in aztec Texcoco, 262-264.

Para evitar el falseamiento de declaraciones, la ley exigía la comprobación del delito, pues el solo testimonio del marido era tenido por nulo, por ello no se ejecutaba la condena hasta la averiguación del caso. En dicha averiguación era necesario que otros testigos imparciales confirmaran las afirmaciones del marido y también era requerida la confesión de los acusados. ${ }^{37}$ Asimismo, todas las personas involucradas en un crimen de adulterio eran condenadas a muerte. Ello incluye las alcahuetas ${ }^{38}$ quienes eran condenadas sobre la base de evidencia indirecta y su pena era el estrangulamiento (véase esquema 1). ${ }^{39}$

Por otra parte, si el marido tomaba la justicia por su propia mano matando a su esposa que le había sido infiel, aunque la hubiera hallado in fraganti, moría por ello, porque usurpaba el oficio de la justicia,

${ }^{37}$ Historia de los mexicanos, 91; Éstas son leyes, 103; Torquemada, Monarquía Indiana, I, 229; IV, 105.

${ }^{38} \mathrm{La}$ alcahueta es comparada con un ratón porque anda a escondidas engañando a las mujeres, las embauca (Sahagún, Historia general, II, 880).

${ }^{39}$ Alva Ixtlilxochitl, Historia de la nación chichimeca, 102. 
pues, debía llevar su denuncia a los jueces para que una vez averiguada la verdad, los acusados murieran por sentencia y no por la sola pasión del marido. ${ }^{40}$

De igual manera, la pena de muerte alcanzó al esposo ofendido cuando no cumplió con lo establecido por la ley y perdonaba a su mujer adúltera. ${ }^{41}$ El perdonar era entendido como dar consentimiento al crimen cometido por ella. Sin embargo, $\operatorname{Pomar}^{42}$ dice que la parte ofendida podía hacerlo y así salvar a su pareja de la sentencia.

Alva Ixtlilxochitl narra un caso en el que el marido no es ejecutado capitalmente pero sí es castigado. En una fiesta, una mujer conoció a Nezahualpilli de quien se enamoró. Después de tener relaciones sexuales, ella le confesó que estaba casada con un varón de nombre Teanatzin. Al enterarse el tlatoani de esta situación "la mandó matar y darle garrote y llevarla a echar en una barranca en donde se echaban los adúlteros y adúlteras". ${ }^{43}$

Cuando el marido se enteró de la suerte de su esposa, se llenó de tristeza y reprochó la respuesta del tlatoani. Nezahualpilli fue informado del desacuerdo del marido por la condena impuesta; por ello, lo "mandó poner a este caballero en unos calabozos aprisionado, con intento de castigarle con castigo que fuese conforme merecía su respuesta y poca estimación de su honra". ${ }^{44}$

En el caso de que los adúlteros hubieran matado al engańado existía un castigo específico. El varón moría asado vivo, y mientras se iba asando, lo iban rociando con agua y sal hasta que allí perecía; y a la mujer la ahorcaban (figura 4$).{ }^{45}$

No se permitía el mal ejemplo en gobernados y mucho menos en gobernantes. Entre los pipiltin se castigaba el delito de manera privada en su casa o en la cárcel, con ahorcamiento. Les emplumaban la

${ }^{40}$ Éstas son leyes, 103; Mendieta, Historia eclesiástica indiana, I, 258; Torquemada, Monarquia Indiana, IV, 105.

${ }^{41}$ Historia de los mexicanos, 85; Éstas son leyes, 103; Motolinía, Memoriales, 321.

${ }^{42}$ Relación de Tezcoco, 183.

${ }_{33}^{4}$ Alva Ixtlilxochitl, Historia de la nación chichimeca, 172.

${ }^{44}$ Idem.

${ }^{45}$ Mohar, Códice Mapa Quinatzin, lám. 3, 288; Mendieta, Historia eclesiástica indiana, I, 258; Alva Ixtlilxochitl, Historia de la nación chichimeca, 102. 
Figura. 4. Códice Mapa Quinatzin, lám. 3
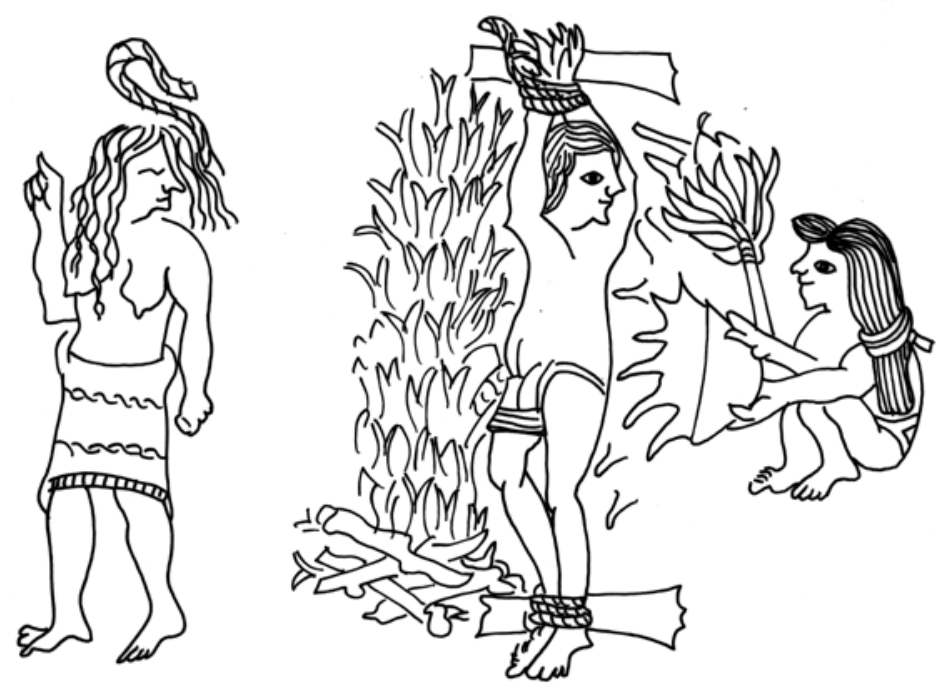

Dibujo de Miriam López.

\section{ESQUEMA 2}

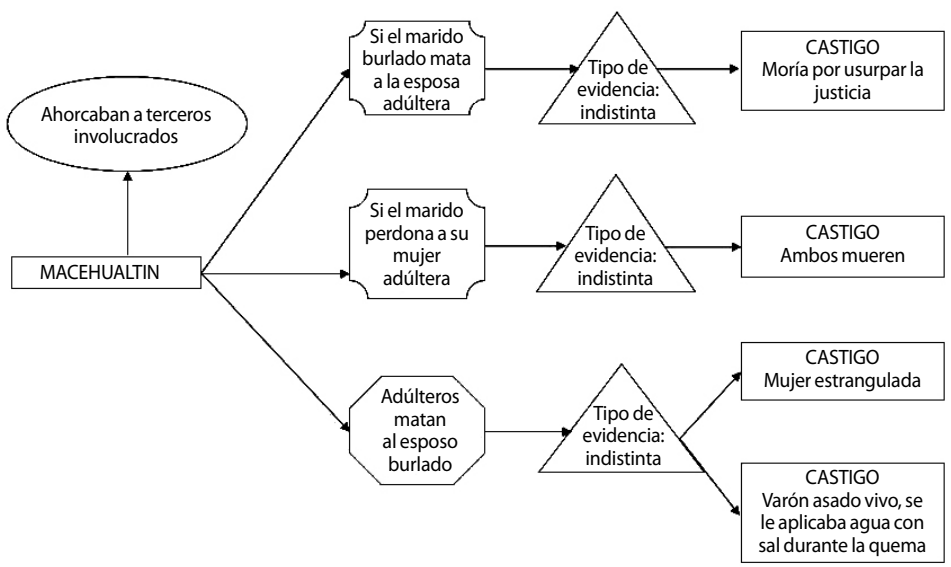


Figura 5. Códice Florentino, vol. 2, fol. 27r.
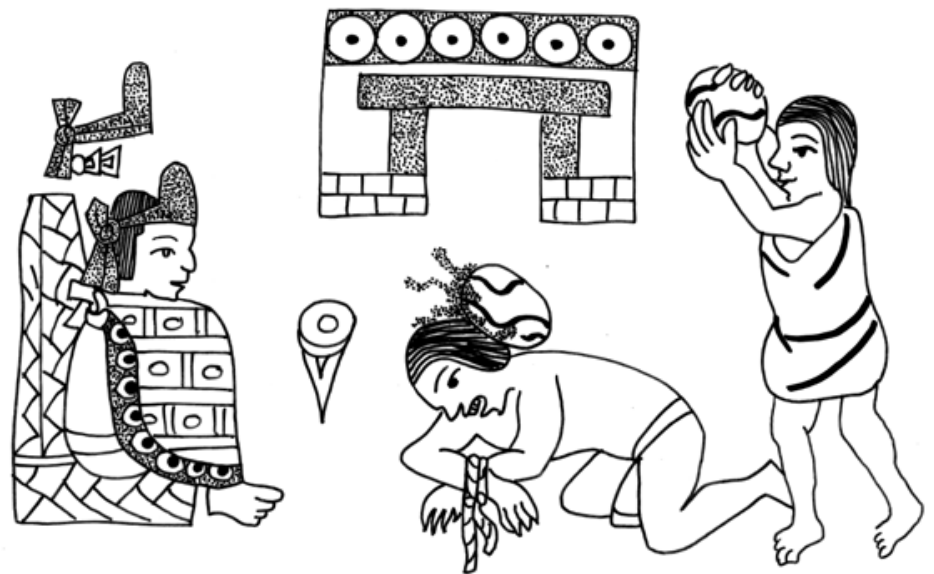

Dibujo de Miriam López.

cabeza con unos penachos verdes y con este atavío los quemaban. ${ }^{46}$ Se observa que se les dispensaba con una pena más gentil, menos escandalosa, menos humillante: sin sufrir la vergüenza pública ni ellos ni sus familias. ${ }^{47}$ Esto era con el fin de no enfrentarlos a las pedradas por parte de los macehualtin. Sin embargo, el Códice Florentino señala que un noble de nombre Uitznauatl Ecamalacotl fue llevado ante Moctezuma por cometer adulterio y él lo condenó a ser apedreado frente a todo el pueblo (figura 5). ${ }^{48}$ En Tlaxcala, el hermano de Maxiscatzin, noble y gobernante, cometió adulterio y murió por ello, pues, no se hacía acepción de personas por clase social. ${ }^{49}$

Otro caso especial fue el de Chalchiuhnenetzin, hija de Axayacatzin, gobernante de México, quien se casó con Nezahualpilli cuando

${ }^{46}$ Mendieta, Historia eclesiástica indiana, I, 258; Alva Ixtlilxochitl, Historia de la nación chichimeca, 102; Torquemada, Monarquía Indiana, IV, 105, 107.

${ }^{47}$ Offner, Law and politics in aztec Texcoco, 261.

${ }^{48}$ Sahagún, Florentine Codex, lib. 8, 42-43.

${ }^{49}$ Alonso de Zorita, Breve y sumaria relación de los señores de la Nueva España (México: UNAM, Biblioteca del estudiante universitario, 1963), 56. 
ESQUEMA 3

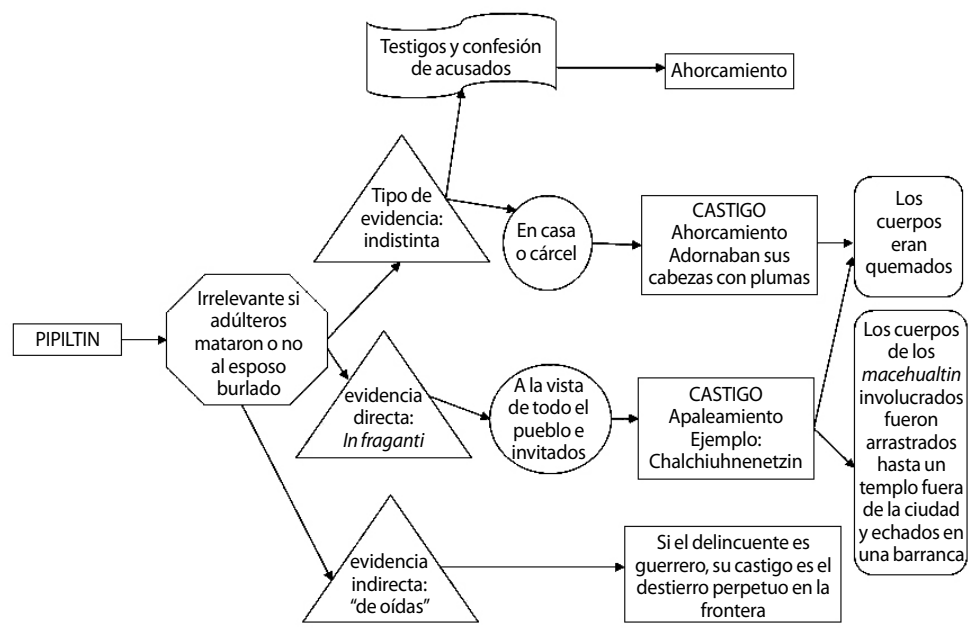

aún era niña. La joven tuvo muchos amantes a quienes mataba y luego mandaba hacer estatuas de ellos. Cuando el tlatoani reconoció una de sus joyas en uno de los jóvenes y sospechó la traición, se dirigió al cuarto de la joven a quien encontró con tres amantes: Chicuhcoatl, Huitzilihuitl y Maxtla. Los cuatro fueron condenados a morir apaleados y luego quemaron sus cuerpos a la vista de todo el pueblo. Este proceso fue excepcional debido a la gravedad de la ofensa al tlatoani. Se decidió que el cumplimiento de la sentencia fuera público, se envió por todo el imperio a llamar a todos los señores para que trajeran a sus hijas y observaran el ejemplar castigo que se ejecutaría. Murieron más de dos mil personas por encubrir el delito. ${ }^{50}$

Finalmente, cuando el delincuente era un guerrero destacado, no se le ejecutaba sino que por decreto se le enviaba a una guarnición localizada en alguna de las fronteras mexicanas, allí era de utilidad para la protección y el aseguramiento de la expansión del imperio. ${ }^{51}$

Se desconoce la frecuencia con que esta transgresión era cometida. Sin embargo, como se ha podido observar los textos refieren que

${ }^{50}$ Alva Ixtlilxochitl, Historia de la nación chichimeca, 164-165.

${ }^{51}$ Ibid., p. 171. 
la sociedad reaccionaba con violencia ante ésta. En otras regiones el adulterio también se castigaba. De acuerdo al caso y la cultura, para la aplicación de la pena se tomaba en cuenta la clase social y sexo del criminal, asimismo, la persona con quien había cometido el delito, y si existía evidencia directa o indirecta. En ciertos casos había una advertencia antes de aplicar la pena de muerte. El tipo de sentencia difiere de las aplicadas entre los nahuas.

\section{EL CASTIGO EN OTROS GRUPOS ${ }^{52}$}

Entre los purépechas se decía que si el marido sorprendía a su mujer con otro les hendía las orejas a ambos, en señal que los había tomado en adulterio; y les quitaba las mantas y las mostraba al que tenía cargo de hacer justicia y esto era creído por aquella señal. ${ }^{53}$

En la Relación ${ }^{54}$ se representan algunos de los modos de castigar las penas "de la justicia que hacía el cazonci", quien como en otras pinturas del documento, está sentado en la puerta de su casa con su diadema, su arco y sus flechas presenciando la ejecución de la sentencia a unos adúlteros: una mujer a la que rasgan la boca y saltan los ojos, que tiene atada una soga al pie con la que después la arrastraran, y a los lados dos hombres, ambos adúlteros, a los que se castiga clavándoles una larga cuńa de madera en sus partes genitales valiéndose de las porras o macanas como martillos (figura 6).

Si algún principal tomaba alguna mujer de las del cazonci, el castigo era la pena de muerte para él, sus hijos, su mujer, sus parientes, y todos los de su casa, pues, eran traidores por no haber avisado lo que estaba sucediendo. Asimismo, se le quitaba toda su hacienda, sus sementeras y las insignias de hombre valiente. ${ }^{55}$ La extensión de la pena a la familia viviente del culpable y en algunos pueblos hasta la segunda, tercera o cuarta generación era un tipo de castigo no basado en un interés social, sino en el desagrado del que ejercía la autoridad.

${ }^{52}$ En el apartado se exponen los datos de algunas fuentes.

${ }^{53}$ Relación de Michoacán, estudio introductorio de Jean-Marie G. Le Clézio (Zamora: El Colegio de Michoacán, 2008), 14, 75.

${ }^{54}$ Ibid., p. 202.

${ }^{55}$ Ibid., p. 203. 
Figura 6. Relación de Michoacán.

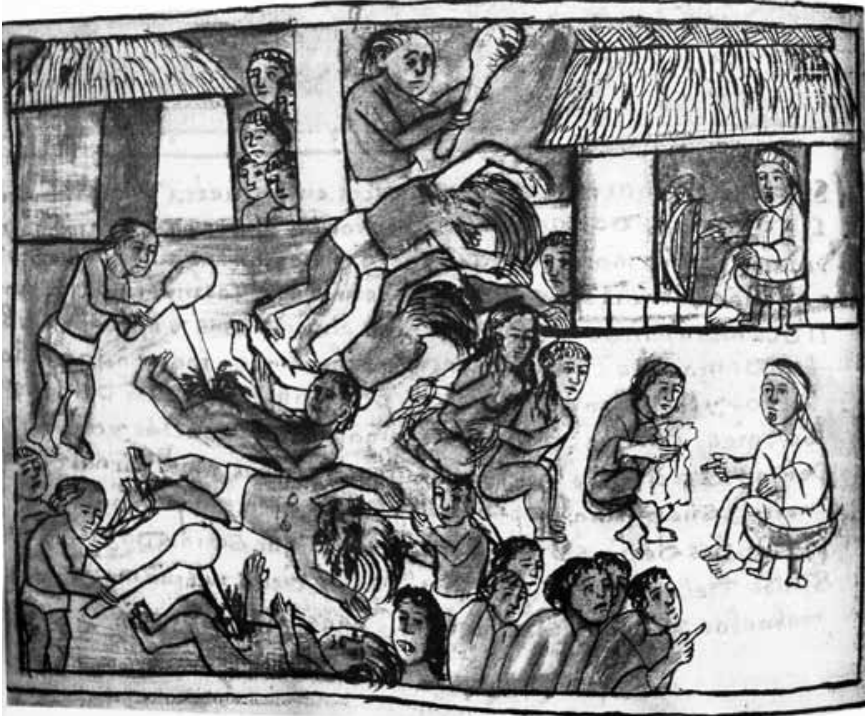

Fuente: Fray Jerónimo de Alcalá (1508-1545). Relación de Michoacán. Zamora: El Colegio de Michoacán, Gobierno del Estado de Michoacán, 2000.

Entre los yopes, grupo que vivía en la región montañosa de la Sierra Madre del Sur, entre Guerrero y Oaxaca, antes de aplicar la pena se hacía una advertencia: el marido "cornudo" quitaba con los dientes las narices a su mujer y al adúltero y con esto quedaban libres, pero si por segunda vez adulteraban aunque fuera con diferentes personas los apedreaban (figura 7). ${ }^{56}$

Entre los mayas de Yucatán, Las Casa $^{57}$ menciona que se multaba al varón que estando casado tenía relaciones con una mujer soltera, pues, en este caso, el padre de la muchacha consideraba que afectaba

${ }^{56}$ Costumbres, fiestas, enterramientos y diversas formas de proceder de los indios de Nueva España, en Tlalocan, vol. 2, publicado por Federico Gómez de Orozco, 1945, fol. 380v, 61; Códice Tudela, edición fascimilar del original existente en el Museo de América de Madrid, comp. José Tudela (Madrid: Instituto de Cooperación Iberoamericana, Editorial Cultura Hispánica, 1980), lám. 75r.

${ }^{57}$ Apologética historia sumaria, II, 521. 
Figura 7. Códice Tudela, lám. 75r.

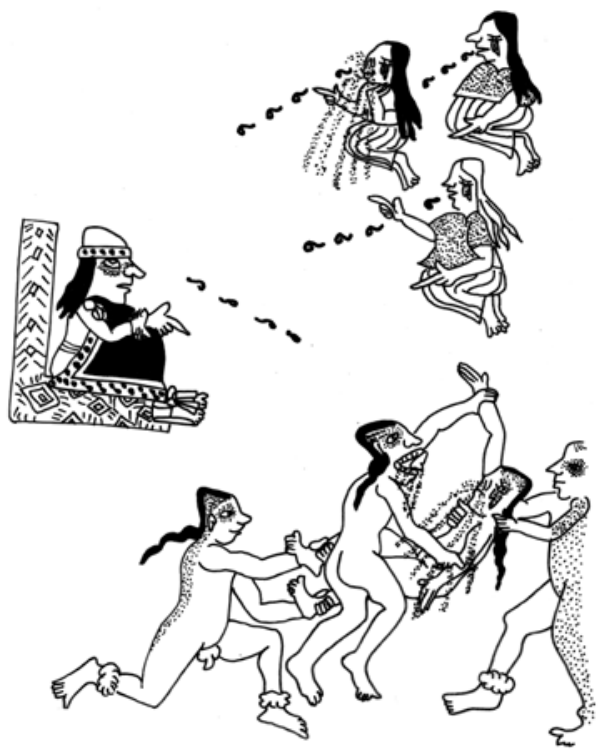

Dibujo de Miriam López.

su derecho a decidir sobre el matrimonio de su hija. La multa era de 100 plumas.

Para la misma región, López de Cogolludo (citando a Gaspar Antonio Chi $)^{58}$ señala penas como el flechamiento y el estacamiento para los adúlteros. Algunas veces al que no se le probaba el adulterio, o le hallaban a deshora en parte sospechosa, le prendían, y le ataban las manos por detrás por un día u horas, o le desnudaban, o le cortaban los cabellos (que era una afrenta severa) según la gravedad de los indicios.

Fray Diego de Landa ${ }^{59}$ explica que al adúltero se le ataba a un palo y lo entregaban al marido; si él lo perdonaba quedaba libre, si

${ }^{58}$ Diego López de Cogolludo, Historia de Yucatán, prólogo de Jorge Ignacio Rubio Mañé, 5a. ed., vol. I (México: Editorial Academia Literaria, 1957), 181-182.

${ }^{59}$ Fray Diego de Landa, Relación de las cosas de Yucatán, Colección Cien de México, estudio preliminar, cronología y revisión del texto de María del Carmen León Cázares (México: Conaculta, 2003), 131. 
Cuadro i. Castigo por adulterio en otros pueblos

\begin{tabular}{|c|c|c|c|c|c|}
\hline Lugar & $\begin{array}{l}\text { Clase } \\
\text { social } \\
\text { criminal }\end{array}$ & $\begin{array}{l}\text { Sexo } \\
\text { criminal }\end{array}$ & Evidencia & Advertencia & $\begin{array}{l}\text { Castigo } \\
\text { (si persistian) }\end{array}$ \\
\hline \multirow[t]{3}{*}{$\begin{array}{l}\text { Michoacán } \\
\text { (purépechas) }\end{array}$} & Indistinta & Indistinto & Directa & $\begin{array}{l}\text { El marido } \\
\text { burlado les } \\
\text { hendía las } \\
\text { orejas a } \\
\text { ambos }\end{array}$ & \\
\hline & Indistinta & Indistinto & Indistinta & No había & $\begin{array}{l}\text { Mujer: le } \\
\text { rasgaban la boca } \\
\text { y saltaban los } \\
\text { ojos, Varón: le } \\
\text { enterraban una } \\
\text { cuña de madera } \\
\text { en sus genitales } \\
\text { con ayuda de un } \\
\text { martillo }\end{array}$ \\
\hline & $\begin{array}{l}\text { Principal } \\
\text { tomaba } \\
\text { mujer de } \\
\text { cazonci }\end{array}$ & Masculino & Indistinta & No había & $\begin{array}{l}\text { Le mandaban } \\
\text { matar a él, a sus } \\
\text { hijos, a su mujer, } \\
\text { a sus parientes; } \\
\text { le tomaban } \\
\text { su hacienda } \\
\text { y sementeras; } \\
\text { le quitaban la } \\
\text { insignia de hom- } \\
\text { bre valiente }\end{array}$ \\
\hline $\begin{array}{l}\text { Entre } \\
\text { Guerrero } \\
\text { y Oaxaca } \\
\text { (Sierra Madre } \\
\text { del Sur) (Yope } \\
\text { o tenitl) }\end{array}$ & Indistinta & Indistinto & Directa & $\begin{array}{l}\text { El marido } \\
\text { burlado } \\
\text { desnarigaba } \\
\text { a ambos }\end{array}$ & $\begin{array}{l}\text { Ambos mueren } \\
\text { por lapidación }\end{array}$ \\
\hline $\begin{array}{l}\text { Yucatán } \\
\text { (mayas) }\end{array}$ & Indistinta & $\begin{array}{l}\text { Masculino } \\
\text { (casado } \\
\text { lo comete } \\
\text { con don- } \\
\text { cella) }\end{array}$ & Indistinta & $\begin{array}{l}\text { Multa de } \\
100 \text { plumas } \\
\text { por afectar } \\
\text { el derecho } \\
\text { del padre } \\
\text { a decidir } \\
\text { sobre el ma- } \\
\text { trimonio de } \\
\text { su hija }\end{array}$ & \\
\hline
\end{tabular}


Cuadro i. Castigo por adulterio en otros pueblos (continuación)

\begin{tabular}{|c|c|c|c|c|c|}
\hline Lugar & $\begin{array}{l}\text { Clase } \\
\text { social } \\
\text { criminal }\end{array}$ & $\begin{array}{l}\text { Sexo } \\
\text { criminal }\end{array}$ & Evidencia & Advertencia & $\begin{array}{l}\text { Castigo } \\
\text { (si persistian) }\end{array}$ \\
\hline & Indistinta & Indistinto & Indistinta & No había & $\begin{array}{l}\text { Flechamiento } \\
\text { Estacamiento }\end{array}$ \\
\hline & Indistinta & Indistinto & $\begin{array}{l}\text { Indirecta } \\
\text { (sin pro- } \\
\text { banza) }\end{array}$ & No había & $\begin{array}{l}\text {-Atados de } \\
\text { manos por un } \\
\text { día u horas } \\
\text {-Desnudaban } \\
\text {-Cortaban el } \\
\text { cabello }\end{array}$ \\
\hline & Indistinta & Masculino & Indistinta & No había & $\begin{array}{l}\text { Al adúltero } \\
\text { atado a un palo } \\
\text { lo entregaban } \\
\text { al marido, si él } \\
\text { lo perdonaba } \\
\text { quedaba libre, } \\
\text { de lo contrario } \\
\text { le quebraban la } \\
\text { cabeza con una } \\
\text { losa }\end{array}$ \\
\hline
\end{tabular}

no, lo mataban dejándole caer una gran piedra sobre la cabeza (véase cuadro 1).

Entre los mayas de Guatemala, el adúltero que transgredía con una mujer del señor era ahogado o vendido para ser sacrificado; por otra parte, si algún hombre tenía relaciones con una mujer esclava dentro de la casa, a ambos les quebraban la cabeza con dos piedras, o les enterraban un palo en la garganta o los apaleaban. ${ }^{60}$

En este mismo grupo, fray Juan de Torquemada ${ }^{61}$ expone que si la mujer del rey cometía adulterio, se tomaba en cuenta la clase social del adúltero, si era principal los apaleaban a ambos; si era común, lo despeńaban. Por otra parte, dice que al que adulteraba con mujer casada era multado con 100 plumas, pero si la falta era habitual los apaleaban a ambos. La misma multa aplicaba al que tenía relaciones con una doncella. ${ }^{62}$

${ }^{60}$ Las Casas, Apologética historia sumaria, II, 518-521.

${ }^{61}$ Monarquia Indiana, IV, 116.

${ }^{62}$ Ibid., pp. 122-124. 
Cuadro 2. Castigo por adulterio en otros pueblos (continuación)

\begin{tabular}{llllll}
\hline Lugar & $\begin{array}{l}\text { Clase } \\
\text { social } \\
\text { criminal }\end{array}$ & $\begin{array}{l}\text { Sexo } \\
\text { criminal }\end{array}$ & Evidencia & Advertencia & $\begin{array}{l}\text { Castigo } \\
\text { (si persistian) }\end{array}$ \\
\hline $\begin{array}{l}\text { Guatemala } \\
\text { (mayas) }\end{array}$ & Indistinta & Masculino Indistinta & No había & $\begin{array}{l}\text { Ahogamiento o } \\
\text { lo vendían para } \\
\text { sacrificio }\end{array}$
\end{tabular}

Indistinta Masculino Indistinta No había Si tenía relaciones con esclava, a ambos les quebraban la cabeza con 2 piedras, o les enterraban un palo en la garganta o los apaleaban

Mujer del Femenino Indistinta No había rey

- Si fue principal con quien cometió adulterio: apaleamiento a él -Si fue común con quien cometió adulterio: a él lo despeñaban

\begin{tabular}{|c|c|c|c|c|}
\hline Indistinta & Masculino & Indistinta & $\begin{array}{l}\text { Multa } \\
\text { de } 100 \\
\text { plumas }\end{array}$ & $\begin{array}{l}\text { Apaleamiento a } \\
\text { ambos }\end{array}$ \\
\hline Indistinta & $\begin{array}{l}\text { Masculino } \\
\text { (casado } \\
\text { lo comete } \\
\text { con don- } \\
\text { cella) }\end{array}$ & Indistinta & $\begin{array}{l}\text { Multa de } \\
100 \text { plumas } \\
\text { por afectar } \\
\text { su futuro } \\
\text { casamiento }\end{array}$ & \\
\hline Indistinta & $\begin{array}{l}\text { Masculino } \\
\text { (casado } \\
\text { lo comete } \\
\text { con viuda } \\
\text { o casada) }\end{array}$ & Indistinta & $\begin{array}{l}\text { A ambos } \\
\text { atados de pies } \\
\text { y manos los } \\
\text { suspendían } \\
\text { y les ponían } \\
\text { debajo una } \\
\text { hierba con } \\
\text { la cual los } \\
\text { ahumaban }\end{array}$ & Morían ambos \\
\hline
\end{tabular}


Cuadro 2. Castigo por adulterio en otros pueblos (continuación)

\begin{tabular}{|c|c|c|c|c|c|}
\hline Lugar & $\begin{array}{l}\text { Clase } \\
\text { social } \\
\text { criminal }\end{array}$ & $\begin{array}{l}\text { Sexo } \\
\text { criminal }\end{array}$ & Evidencia & Advertencia & $\begin{array}{l}\text { Castigo } \\
\text { (si persistian) }\end{array}$ \\
\hline Perú & Indistinta & Indistinto & Indistinta & No había & $\begin{array}{l}\text {-Ambos eran } \\
\text { lapidados, no } \\
\text { se les enterraba } \\
\text { y los buitres } \\
\text { devoraban sus } \\
\text { cuerpos } \\
\text {-Ahorcamiento } \\
\text {-Enterramiento } \\
\text { de los adúlteros } \\
\text { vivos }\end{array}$ \\
\hline
\end{tabular}

También menciona que en el caso de transgredir con viuda o con casada, los castigaban una o dos veces, pero si persistían, los ataban de manos por las espaldas y los suspendían en el aire, así suspendidos les ponían debajo una hierba de mal olor con la cual les echaban humo y con este castigo quedaba pagada la culpa, pero si no se enmendaban pagaban con la vida.

En el Perú, Cieza de León ${ }^{63}$ dice que el adulterio se castigaba con lapidación, no se les enterraba sino que se les dejaba a la intemperie para que los buitres los devoraran, en otros casos se les ahorcaba o se les enterraba vivos (véase cuadro 2).

\section{LOS SISTEMAS JURÍDICOS NAHUAS}

En los estados nahuas el aparato jurídico se encontraba integrado firmemente al poder político y viceversa. Era una institución de gobierno administrada por "una burocracia de funcionarios bajo las órdenes del supremo gobernante" ${ }^{64}$ Constituía una muestra de la alta organización que existía en las urbes del centro de México. ${ }^{65}$

${ }^{63}$ Pedro Cieza de León, La crónica del Perú, Colección Grandes Viajes 24 (Madrid: Espasa-Calpe, 1932), 116.

${ }^{64}$ Johanna Broda, "El aparato jurídico del Estado mexica: algunas reflexiones acerca de lo público y lo privado en el México prehispánico", Nueva Antropología x(36) (1989): 52.

${ }^{65}$ Ibid., p. 55. 
Los sistemas jurídicos nahuas tuvieron un carácter "restrictivo, ejemplar y punitivo", 66 pues, su objetivo no fue rehabilitar a los transgresores, sino prevenir la comisión futura del delito por el mismo individuo o por otro. Por ello, la ejecución de la sentencia tenía que constituir un espectáculo público.

El castigo físico logró una clase muy directa de ejemplaridad, pero en los distintos tipos de delitos, las ejecuciones fueron las penas por excelencia para el pueblo. Es así que la nobleza y el clero, elites dirigentes del mundo mesoamericano, tuvieron las prerrogativas de la violencia.

Como observamos, en la imposición de la pena se tomaban en cuenta factores como el tipo de evidencia, las circunstancias que acompańaban el caso, la clase social (rango u oficio) y el género. Paralelamente, existieron ciertos principios que rigieron la práctica judicial.

Recordemos que para evitar el falseamiento de declaraciones, la ley exigía la comprobación del delito, pues el solo testimonio de una persona era tenido por nulo, por ello no se ejecutaba la condena hasta la averiguación del caso. Asimismo, se requería la confesión de los acusados. ${ }^{67}$ De igual manera, tomar la justicia por propia mano era penado ${ }^{68} \mathrm{y}$, por último, otorgar el perdón al transgresor (por parte de su familia) era visto como dar consentimiento a la falta cometida por él. ${ }^{69}$

Los castigos al adulterio en la antigua sociedad nahua no incluyen penas no físicas ${ }^{70}$ a diferencia de otros pueblos, por ejemplo,

${ }^{66}$ Carlos Brokmann, La estera y la silla. Individuo, comunidad, estado e instituciones jurídicas nahuas (México: Comisión Nacional de los Derechos Humanos, 2006), 114.

${ }^{67}$ Historia de los mexicanos, 91; Estas son leyes, 103; Torquemada, Monarquía Indiana, I, 229; IV, 105.

${ }^{68}$ Éstas son leyes, 103; Mendieta, Historia eclesiástica indiana, I, 258; Torquemada, Monarquia Indiana, IV, 105.

${ }^{69}$ Historia de los mexicanos, 85; Estas son leyes, 103; Motolinía, Memoriales, 321.

${ }^{70}$ En el caso de la embriaguez, el castigo más común aplicado a los macehualtin era que la primera ocasión que delinquían les trasquilaban la cabeza públicamente en la plaza o mercado y su casa era saqueada y tirada (Mendieta, Historia eclesiástica indiana, I, 262; Sahagún, Historia general, I, 252; Alva Ixtlilxochitl, Historia de la nación chichimeca, 102; Francisco Hernández, Antigüedades de la Nueva España, Colección Crónicas de América 28, ed. Ascensión H. de León-Portilla (Madrid: Historia 16, 1986), 72. 
entre los mayas de Yucatán y de Guatemala que ante este delito al varón se le multaba con 100 plumas la primera vez. ${ }^{71}$

A manera de recapitulación, en los sistemas jurídicos nahuas al aplicarse las penas se tomaban en cuenta:

A) El tipo de evidencia. Se puede dividir en directa, es decir, que los transgresores fueron descubiertos in fraganti, y en indirecta, "de oídas". A los adúlteros del primer caso se les lapidaba ${ }^{72}$ o quebraba la cabeza entre losas ${ }^{73}$ o apaleaba; ${ }^{74}$ y en el segundo caso, se le ahorcaba o si era guerrero se le desterraba perpetuamente. ${ }^{75}$

B) Las circunstancias. La pena variaba igualmente según las particularidades que acompańaban al caso, pues, al delito de adulterio se le podía sumar asesinato o cuestionamiento del poder. Por ejemplo, si los adúlteros no matan al esposo burlado; si el marido burlado mata a la esposa adúltera; ${ }^{76}$ si el marido perdona a su mujer adúltera ${ }^{77}$ y si los adúlteros matan al esposo burlado, ${ }^{78}$ las penas son distintas.

C) La clase social (rango u oficio). Hay más variabilidad en la aplicación de las penas a los macehualtin, tenemos: lapidación, apaleamiento, quebramiento de cabeza entre dos losas, ahorcamiento y quema. En la decisión de aplicar una u otra se entrecruzan distintos factores. Lo que no varía es que es público, punto que abordaré más

${ }^{71}$ Las Casas, Apologética historia sumaria, II, 521; Torquemada, Monarquía Indiana, IV, 122-124.

${ }^{72}$ Historia de los mexicanos, 91; Mohar, Códice Mapa Quinatzin, lám. 3, 287; Códice Mendoza, LXXII, lám. 71r; Códice Telleriano-Remensis, XIx, lám. 17r; Códice Vaticano Latino A 3738, xxxvıII, lám. 25r; Mendieta, Historia eclesiástica indiana, I, 259; Sahagún, Historia general, II, 758; Durán, Historia de las Indias, I, 266; Alvarado Tezozomoc, Crónica Mexicana, 501; Alva Ixtlilxochitl, Sumaria relación, I, 385; Torquemada, Monarquía Indiana, Iv, 106. A la mujer previamente se le ahorcaba de acuerdo a los códices Telleriano-Remensis, XIx, lám. 17r y Vaticano Latino A 3738, xxxviII, lám. 25r.

${ }^{73}$ Cervantes de Salazar, Crónica de la Nueva España, 47-48; Pomar, Relación de Tezcoco, 183; Alva Ixtlilxochitl, Relación sucinta, I, 405; Torquemada, Monarquía Indiana, IV, 106.

${ }^{74}$ Mendieta, Historia eclesiástica indiana, I, 258; Sahagún, Historia general, II, 759; Torquemada, Monarquía Indiana, IV, 106.

${ }^{75}$ Alva Ixtlilxochitl, Sumaria relación, 385; Historia de la nación chichimeca, 171.

${ }^{76}$ Estas son leyes, 103; Mendieta, Historia eclesiástica indiana, I, 258; Torquemada, Monarquia Indiana, IV, 105.

${ }_{77}$ Historia de los mexicanos, 85; Estas son leyes, 103; Motolinía, Memoriales, 321.

${ }^{78}$ Mohar, Códice Mapa Quinatzin, lám. 3, 288; Mendieta, Historia eclesiástica indiana, I, 258; Alva Ixtlilxochitl, Historia de la nación chichimeca, 102. 
adelante. Por el contrario, respecto a los castigos para los pipiltin tenemos el ahorcamiento privado (sus cabezas eran adornadas con plumas y sus cuerpos eran cremados). ${ }^{79}$ Valga decir que para transgresiones ejemplares dicha regla varió. ${ }^{80}$

Casos particulares fueron los guerreros y sacerdotes, pues debido a su rango u oficio se les dictaban sentencias especiales ante diferentes delitos. Al ser juzgados y encontrados culpables de transgresiones, los guerreros eran expulsados de este grupo de privilegios y se les rapaba la cabeza como a los tamemes, la más humilde de las ocupaciones mexicas. Igualmente, se les quemaba el mechón ${ }^{81}$ que los distinguía como parte de este grupo, con lo cual probablemente nunca más les crecería debido a las cicatrices. Con esa expulsión perdían la oportunidad de ascenso social y de prestigio local.

Para casos de homosexualidad en el grupo sacerdotal, los quemaban vivos y otro tipo de penas que eran proporcionales a la expectativa que se tenía de ellos, pues, debido a su prestigio se esperaba que ellos fueran los primeros en cumplir con las reglas. ${ }^{82}$

D) El género. Como mencioné al inicio, en la antigua sociedad nahua el adulterio significaba relaciones sexuales con una mujer casada, la fornicación extramatrimonial no constituía ningún delito para el hombre, siempre y cuando su compañera fuera soltera y sin limitaciones formales, por ejemplo, los votos al templo. De esta manera, las concubinas de otros hombres estaban, en apariencia, permitidas. Por tanto, una mujer casada siempre recibiría su castigo, contrariamente a un hombre casado cuya pena sólo se aplicaría en el caso arriba descrito.

${ }^{79}$ Mendieta, Historia eclesiástica indiana, I, 258; Alva Ixtlilxochitl, Historia de la nación chichimeca, 102; Torquemada, Monarquía Indiana, IV, 105, 107.

${ }^{80}$ Zorita, Breve y sumaria relación, 56; Sahagún, Florentine Codex, lib. 8, 42-43; Alva Ixtlilxochitl, Historia de la nación chichimeca, 164-165, 172.

${ }^{81}$ El mechón portaba potencia especial porque se entendía que el tonalli estaba localizado en la parte superior de la cabeza, de modo que al cortar el mechón se debilitaba a la víctima y fortalecía al apresador (Inga Clendinnen, Los aztecas. Una interpretación (México: Editorial Nueva Imagen, 1998), 329; Alfredo López Austin, Cuerpo humano e ideología. Las concepciones de los antiguos nahuas (México: IIA, UNAM, 1996), I, 297.

${ }^{82}$ Estas son leyes, 103; Las Casas, Apologética historia sumaria, II, 400; Zorita, Breve y sumaria relación, 56; Torquemada, Monarquía Indiana, IV, 107. 
Otro ejemplo de diferenciación que contiene ideología de género lo encuentro en las láminas de los códices Telleriano Remensis ${ }^{83} \mathrm{y}$ Vaticano Latino A $3738,{ }^{84}$ las cuales parecen indicar que a las mujeres las ahorcaban antes de lapidarlas, en ese caso habría una distinción por género.

En el proceso del adulterio que incluía el asesinato del marido engañado, ${ }^{85}$ a la mujer no se le castigaba tan severamente como a su pareja pues se creía que ella había sido corrompida por otra persona. Por tanto, al instigador se le aplicaba la pena más dolorosa y temporalmente más larga que a la incitada. ${ }^{86}$

\section{JERARQUía DE LOS CASTIGOS}

Indudablemente el sufrimiento es parte de la sentencia-penitencia por cumplir, si el castigo fuera sólo la muerte no existirían distintas penas de acuerdo al delito y las circunstancias. El sufrimiento es parte del precio que se tiene que pagar por la violación del orden.

La vergüenza es el inicio del sufrimiento, tanto el transgresor como su familia viven la humillación ante la sociedad. Igualmente, la primera línea de defensa que tenía la comunidad ante los posibles transgresores era precisamente la vergüenza; ésta era una formidable arma "cara a cara" de la colectividad. La vergüenza y la consecuente desmoralización de los transgresores fue el principio del castigo.

Distintas sociedades han implantado diferentes clases de castigos, la antigua sociedad nahua no fue la excepción. En su sistema judicial encontramos: 1) castigo-advertencia; 2) castigo capital instantáneo; y 3) castigo capital prolongado.

El primer rango se entendía como "apenas ha escapado a la muerte", la próxima vez será castigado capitalmente. Mencioné que a los guerreros les rapaban la cabeza al ser hallados culpables de

${ }^{83}$ Códice Telleriano-Remensis, xIx, lám. 17r.

${ }^{84}$ Códice Vaticano Latino A 3738, xxxviII, lám. 25 r.

${ }^{85}$ Mohar, Códice Mapa Quinatzin, lám. 3, 288; Mendieta, Historia eclesiástica indiana, I, 258; Alva Ixtlilxochitl, Historia de la nación chichimeca, 102.

${ }^{86}$ Offner, Law and politics in aztec Texcoco, 265-266. 
transgresiones, igualmente los borrachos corrían con esta suerte, ${ }^{87}$ pero sólo la primera vez, la segunda vez serían muertos. ${ }^{88}$

El mismo castigo-advertencia recibían las alcahuetas de los estamentos inferiores, a quienes se les exhibía públicamente en la plaza $\mathrm{y}$ ante todos los presentes "quemaban los cabellos con tea encendida hasta que se calentaba lo vivo de la cabeza, y así afrentada y conocida, que los cabellos quemaban chamuscados, se iba" ${ }^{89} 90$

Como mencioné, el quemar o rapar los cabellos se consideraba algo peligroso, pues, con ello se exponía al transgresor a la pérdida del tonalli, una de las entidades anímicas del ser humano. De acuerdo con López Austin, ${ }^{91}$ el cabello era recipiente de fuerza, que formaba una capa protectora en la cabeza para evitar la salida de esta entidad, y si se dañaba, la persona se enfermaría o moriría. ${ }^{92}$

En otros pueblos también existieron las penas-advertencias para las transgresiones sexuales. Como indiqué líneas atrás, entre los mayas de Guatemala y Yucatán se multaba con 100 plumas al adúltero; igualmente, se practicaba ahumarlos con una hierba. En Michoacán, a los homosexuales pasivos se les encarcelaba y si reincidían se les sacrificaba. ${ }^{93}$ En Guatemala, en caso de que se comprobara un intento de violación, al criminal se le convertiría en esclavo. $^{94}$

${ }^{87}$ Mendieta, Historia eclesiástica indiana, I, 262; Sahagún, Historia general, I, 252; Alva Ixtlilxochitl, Historia de la nación chichimeca, 102; Hernández, Antigüedades de la Nueva España, 72.

${ }^{88}$ También se menciona que la pena para el primerizo era ser vendido como esclavo y a la siguiente se le ahorcaba y apedreaba (Alva Ixtlilxochitl, Relación sucinta, I, 405406).

${ }^{89}$ Mendieta, Historia eclesiástica indiana, I, 259; Torquemada, Monarquía Indiana, IV, 107-108.

${ }^{90}$ La suerte de la alcahueta de los estratos principales era trágicamente diferente ya que se le ejecutaba mediante el ahorcamiento público junto con la persona que hubiera contratado sus servicios (Mendieta, Historia eclesiástica indiana, I, 259; Torquemada, Monarquia Indiana, IV, 107-108).

${ }^{91}$ Cuerpo humano e ideología, I, 242-243.

92 Recordemos que también a los temacpalitotique y a las mometzcopinque les cortaban los cabellos de la corona de la cabeza, por donde perdían el poder que tenían para hacer su magia (Sahagún, Historia general, I, 405).

${ }^{93}$ Relación de Michoacán, 14.

${ }^{94}$ Torquemada, Monarquía Indiana, Iv, 118. 
Igualmente, tenemos a la mutilación como prevención. La mutilación de la nariz, junto con la de las orejas, fue el castigo mexica destinado a los traidores y mentirosos. ${ }^{95}$ No obstante, aunque la mutilación existió en el sistema judicial nahua, no se aplicó para los transgresores sexuales, contrario a otros pueblos.

Entre los yopes, grupo que vivía entre Guerrero y Oaxaca, se desnarigaba a los adúlteros como primera amonestación, a la siguiente los apedreaban. ${ }^{96}$ En tanto, entre los purépechas el marido burlado hendía las orejas a ambos. ${ }^{97}$

Una división relevante en la jerarquía de los castigos es entre aquellos que implican un instante (castigo capital instantáneo) y los que conllevan una muerte más dilatada (castigo capital prolongado).

En el castigo capital instantáneo la pena es dolorosa pero es rápida. En éste considero el ahorcamiento y el quebramiento de la cabeza con dos losas. En el castigo capital prolongado las penas son más dolorosas por el periodo de tiempo que lleva para que éste finalice. En ellas incluyo la lapidación, apaleamiento y la quema o asamiento vivo. Para este último rango de castigos contamos con distintos ejemplos que nos ilustran el sufrimiento del transgresor. Por ejemplo, el asamiento del adúltero con sal. ${ }^{98}$

\section{CAstigo púBlico / CASTIGo PRIVAdo}

La plaza, mercado o tianquiztli tenía un claro significado comunitario, era un lugar abierto y propicio para el encuentro de la sociedad. Igualmente, era un espacio para permanecer y participar, a diferencia de las calles que invitaban al movimiento.

${ }^{95}$ Ibid., I, 288.

${ }^{96}$ Costumbres, fiestas, 61; Códice Tudela, lám. 75r.

${ }^{97}$ Relación de Michoacán, 14, 75.

${ }^{98}$ Mohar, Códice Mapa Quinatzin, lám. 3, 288; Mendieta, Historia eclesiástica indiana, I, 258; Alva Ixtlilxochitl, Historia de la nación chichimeca, 102.

En cuanto al castigo aplicado a los homosexuales, se hacía distinción entre el paciente y el agente. Al paciente le sacaban las entrańas por el sexo, lo cubrían de ceniza y lo quemaban; al agente únicamente lo enterraban en ceniza (Alva Ixtlilxochitl, Historia de la nación chichimeca, 101; Torquemada, Monarquía Indiana, I, 230). 
Económicamente, el mercado fue un espacio para el comercio; pero, políticamente significó un lugar para la concentración, marco para el acontecer social. Era aquí donde se llevaban a cabo las ejecuciones estatales, la multitud que acudía a estos lugares era espectadora y participante de las sentencias. ${ }^{99}$

Dichas exhibiciones se utilizaron para intimidar a los observadores y en el caso de la lapidación para hacerlos cómplices, al pedir la participación de la concurrencia en la ejecución de la pena.

Paralelamente, al ser públicas las sentencias se buscaba que sirvieran de advertencia y escarmiento para que nadie se atreviera a hacer algo semejante. Este método fue una herramienta de intimidación mediante la cual el gobernante de la ciudad principal mostraba su dominio a su población y a otras poblaciones; pues, al invitar a los gobernantes de otras y menores ciudades a presenciar las ejecuciones era una especie de aviso sobre su poder y la sanción que aplicaría a los infractores de su ley.

El ceremonial era importante, pues, implicaba los aspectos formales de una ejecución. Primero se presentaba la acusación; después se investigaban los hechos; en tercer lugar, se dictaba la sentencia; $y$, finalmente, se procedía al castigo del delincuente. ${ }^{100}$ El cumplimiento de la sentencia era una especie de obra de teatro de moralidad.

La exposición del transgresor ante la multitud cumplía con el objetivo de humillar en primer lugar al sentenciado. Como vimos anteriormente, no siempre la pena era capital, algunas veces únicamente se realizaba el marcaje del transgresor, deshonra que lo acompañaría toda su vida. La pena-advertencia es el tipo de castigo público menos severo.

Por otra parte, tenemos el castigo privado. A éste eran sometidos únicamente los pipiltin. La antigua sociedad nahua era altamente jerarquizada y en el sistema judicial como en otras áreas, observa-

${ }^{99}$ Véanse por ejemplo: Códice Telleriano Remensis, xIx, lám. 17r.; Mendieta, Historia eclesiástica indiana, I, 259; Sahagún, Historia general, II, 758-759; Durán, Historia de las Indias, I, 266; Alva Ixtlilxochitl, Historia de la nación chichimeca, 164-165; Torquemada, Monarquia Indiana, IV, 106.

${ }^{100}$ Offner, Law and politics in aztec Texcoco, 250. 
mos dicha distinción. Al ser privado el castigo para los principales se evitaba exponerlos a la vergüenza pública. Igualmente, mediante el ahorcamiento no se les enfrentaba a las pedradas por parte de los macehualtin. Otro dato es que al momento de su muerte se distinguían sus cabezas con penachos. Excepción a la regla fueron los casos de Chalchiuhnenetzin, Uitznauatl Ecamalacotl y del hermano de Maxiscatzin.

\section{Comentarios Finales}

Desde diversas estrategias se buscaba impedir la transgresión, sería un peligro para todos que el caos entrara en la comunidad. La aplicación de las penas cumplía un doble propósito: la advertencia a los transgresores potenciales de la suerte que correrían si en ese sentido actuaran; y la advertencia de tomar la ley en las propias manos, usurpando el oficio de los jueces. En este sentido, las ejecuciones jugaron un rol principal como la parte más conspicua del sistema penal.

Las penas fueron los medios empleados por los grupos dirigentes para mantener a la población bajo control. ${ }^{101}$ Los castigos corporales y capitales muestran la estabilización de los sistemas judiciales nahuas. La imposición de una pena fue el resultado de una decisión y más aún la ejecución de un individuo fue un evento planeado.

Los castigos para los transgresores son congruentes con el sistema de disciplina que se aplicaba desde la niñez en la antigua sociedad nahua. El Estado requería de ciudadanos dispuestos a cumplir con sus obligaciones imperiales. Por ello, desde la infancia se aplicaban fuertes represalias a la desobediencia.

Ilustraciones sobre los castigos a los niños las tenemos en el Códice Mendoza $a^{102}$ donde observamos a infantes siendo corregidos con métodos como azotes y pinchazos con puntas de maguey en todo el cuerpo; también, aparecen atados y colocados sobre tierra húmeda o

${ }^{101}$ No olvidemos que a pesar del rigor de la retórica y de la clara aplicación de castigos estatales, parece que había un cierto grado de asentimiento al interior de los calpulli. Por ello, algunos transgresores no enfrentarían la justicia estatal.

${ }^{102}$ Códice Mendoza, LX-LXI, láms. 56-60. 
inhalando humo de chile o las nińas barriendo a media noche la casa. Indudablemente, era un mundo severo para el que estaban siendo preparados, donde la disciplina debía de ser firme, física e inmediata.

Por otra parte, en una sociedad con una fuerte inclinación masculina como la nahua, el adulterio femenino representaba no sólo una violación a los derechos del varón, sino una demostración de su fracaso en el cumplimiento de su deber, una agresión a él y a los ideales de la sociedad. Por ello se exhortaba a los varones nahuas para que cuidaran celosamente a sus mujeres, pues, la mala conducta de ellas ponía en peligro los ideales del grupo.

Debido a la marcada diferenciación genérica que se establecía desde el nacimiento entre los antiguos nahuas, los papeles y destinos en la vida de hombres y mujeres estaban definidos. Todas las mujeres tenían como meta el matrimonio y, en ese estado, ser una esposa ejemplar. Aunque gozaban de cierto grado de independencia y movilidad en su sociedad, no tenían acceso a los altos puestos políticos ni religiosos. Igualmente, la carrera militar estaba vedada para ellas. $\mathrm{Al}$ interior del hogar, el hombre era el jefe indiscutible de la familia.

En efecto, el rompimiento del contrato nupcial ponía en riesgo la certidumbre del padre de los hijos de una mujer. A la par, en el delito de adulterio, el engańo y el dańo eran asunto entre dos hombres -el que se había apoderado de la mujer y el que tenía derechos legítimos sobre ella-, sin olvidar que las alianzas significaban prestigio y poder.

La defensa del honor masculino fue la defensa de privilegios que habían sido concedidos a los grupos de poder, privilegios otorgados gracias a la división sexual del trabajo, a la opresión de los macehualtin y de otros grupos por la guerra, pues ésta permitió la consolidación de un Estado expansionista. La búsqueda de la administración de los cuerpos fortaleció las bases sociales (matrimonio y familia) y garantizó la salvaguarda de propiedades.

\section{BiBLIOGRAFÍA}

Alcalá, Fray Jerónimo de. Relación de Michoacán. Coordinación de edición y estudios de Moises Franco Mendoza. Zamora: El Colegio de Michoacán, Gobierno del Estado de Michoacán, 2000. 
- Relación de Michoacán. Estudio introductorio de Jean-Marie G. Le Clézio. Zamora: El Colegio de Michoacán, 2008.

Alva IxtLILXochitu, Fernando. Sumaria relación de todas las cosas que han sucedido en la Nueva España, y de muchas cosas que los tultecas alcanzaron y supieron desde la creación del mundo, hasta su destrucción y venida de los terceros pobladores chichimecas, hasta la venida de los españoles, sacada de la original historia de esta Nueva España. En Obras históricas. Tomo I, ed. Edmundo O'Gorman, 262-393. México: Instituto Mexiquense de Cultura, IIH, UNAM, 1997.

Relación sucinta en forma de memorial de la historia de la Nueva España y sus señorios hasta el ingreso de los españoles. En Obras históricas. Tomo I, ed. Edmundo O’Gorman, 395-413. México: Instituto Mexiquense de Cultura, IIH, UNAM, 1997.

. Historia de la nación chichimeca. En Obras históricas. Tomo II, ed. Edmundo O'Gorman, 7-263. México: Instituto Mexiquense de Cultura, IIH, unAM, 1997.

Alvarado Tezozomoc, Fernando. Crónica mexicana. Notas de Manuel Orozco y Berra. México: Editorial Leyenda, 1944.

BrodA, Johanna. "El aparato jurídico del Estado mexica: algunas reflexiones acerca de lo público y lo privado en el México prehispánico”. Nueva Antropología (x)36 (1989): 41-63.

Brokmann, Carlos. La estera y la silla. Individuo, comunidad, estado e instituciones jurídicas nahuas. México: Comisión Nacional de los Derechos Humanos, 2006.

- La justicia en el México prehispánico. México: Suprema Corte de Justicia de la Nación, 2010.

Cervantes de Salazar, Francisco. Crónica de la Nueva España. Prólogo por Juan Miralles Ostos. México: Editorial Porrúa, 1985.

Cieza de León, Pedro. La crónica del Perú. Colección Grandes viajes 24. Madrid: Espasa-Calpe, 1932.

Clendinnen, Inga. Los aztecas. Una interpretación. México: Editorial Nueva Imagen, 1998.

Códice Borbónico, Manuscrito mexicano de la biblioteca del Palais Bourbon: libro adivinatorio y ritual ilustrado. Descripción, historia y exposición del Códice Borbónico por Francisco del Paso y 
Troncoso. Comentario explicativo por E. T. Hamy. Edición facsimilar. México: Siglo XXI editores, 1993.

Códice Mendoza. En Antigüedades de México. Vol. I. Recopilador Lord Kingsborough. Palabras preliminares de Antonio Ortiz Mena. Prólogo de Agustín Yánez. Estudio e interpretación de José Corona Núñez. México: SHCP, 1964, 1-149.

Códice Telleriano-Remensis. En Antigüedades de México. Vol. I. Recopilador Lord Kingsborough. Palabras preliminares de Antonio Ortiz Mena. Prólogo de Agustín Yánez. Estudio e interpretación de José Corona Núñez. México: SHCP, 1964, 151-337.

Códice Tudela. Edición facsimilar del original existente en el Museo de América de Madrid. Comp. José Tudela. Madrid: Instituto de Cooperación Iberoamericana, Editorial Cultura Hispánica, 1980. Códice Vaticano Latino A 3738. En Antigüedades de México. Vol. III. Recopilador Lord Kingsborough. Palabras preliminares de Antonio Ortiz Mena. Prólogo de Agustín Yánez. Estudio e interpretación de José Corona Núnéz. México: SHCP, 1964, 1-314.

Costumbres, fiestas, enterramientos y diversas formas de proceder de los indios de Nueva España. En Tlalocan. Vol. 2. Publicado por Federico Gómez de Orozco, 1945, 37-63.

Durán, fray Diego. Historia de las Indias de Nueva España e islas de tierra firme. Tomos I, II. México: Conaculta, Colección Cien de México, 2002.

Éstas son leyes que tenían los indios de la Nueva España, Anáhuac o México. En Mitos e historias de los antiguos nahuas. Colección Cien de México. Traducción y paleografía de Rafael Tena. México: Conaculta, 2002, 96-111.

García Quintana, Josefina. "Exhortación de un padre a su hijo. Texto recogido por Andrés de Olmos". Estudios de Cultura Náhuatl, vol. 11 (1974): 137-182.

Hernández, Francisco. Antigüedades de la Nueva España. Colección Crónicas de América 28, ed. Ascensión H. de León-Portilla. Madrid: Historia 16, 1986.

Historia de los mexicanos por sus pinturas. En Mitos e historias de los antiguos nahuas. Colección Cien de México. Traducción y paleografía de Rafael Tena. México: Conaculta, 2002, 13-95. 
Landa, fray Diego de. Relación de las cosas de Yucatán. Colección Cien de México. Estudio preliminar, cronología y revisión del texto de María del Carmen León Cázares. México: Conaculta, 2003.

Las Casas, fray Bartolomé de. Apologética historia sumaria. Cuanto a las cualidades, disposición, descripción, cielo y suelo destas tierras, y condiciones naturales, policías, repúblicas, manera de vivir e costumbres de las gentes destas Indias occidentales y meridionales cuyo imperio soberano pertenece a los reyes de Castilla. Tomo II. Edición preparada con un estudio preliminar, apéndices y un índice de materias por Edmundo O'Gorman. México: IIH, UNAM, 1967.

López Austin, Alfredo. La Constitución real de México-Tenochtitlan. México: UnAM, 1961.

. Educación mexica: antología de documentos sahaguntinos. Selección, paleografía, traducción, introducción, notas y glosario de Alfredo López Austin. México: IIA, unAm, 1985.

. Cuerpo humano e ideología. Las concepciones de los antiguos nahuas. Vol. I. México: IIA, UNAM, 1996,

López de Cogolludo, Diego. Historia de Yucatán. 5a. ed. Vol. I. Prólogo de Jorge Ignacio Rubio Mañé. México: Editorial Academia Literaria, 1957.

López Hernández, Miriam. "Las transgresiones sexuales entre los nahuas prehispánicos”. Tesis de Maestría en Antropología, FFyL, IIA, UNAM, 2009.

Mendieta, fray Gerónimo de. Historia eclesiástica indiana. Colección Cien de México. Tomo I. Noticias del autor y de la obra por Joaquín García Icazbalceta. Estudio preliminar de Antonio Rubial García. México: Conaculta, 2002.

Mendieta y NúÑEz, Lucio. "El derecho mexicano antes de la conquista”. Ethnos I(8-12) (1922): 168-186.

Mohar Betancourt, Luz María. Códice Mapa Quinatzin. Justicia $y$ derechos humanos en el México antiguo. México: CNDH, CIESAS, Miguel Ángel Porrúa, 2004.

Molina, fray Alonso de. Vocabulario en lengua castellana y mexicana y mexicana y castellana. Estudio preliminar por Miguel LeónPortilla. México: Editorial Porrúa, 2004. 
Motolinía, fray Toribio de Benavente. El libro perdido: ensayo de reconstrucción de la obra histórica extraviada de fray Toribio, dir. Edmundo O'Gorman. México: Conaculta, 1989. . Memoriales o Libro de las cosas de la Nueva España y de los naturales de ella. Serie de Historiadores y Cronistas de Indias 2a. ed. Edmundo O'Gorman. México: IIH, UNAM, 1971.

Offner, Jerome. Law and politics in aztec Texcoco. Cambridge: Cambridge University Press, 1983.

Pomar, Juan Bautista de. Relación de Tezcoco. En Poesía Nábuatl I, Romances de los Señores de la Nueva España. Paleografía, versión, introducción, notas y apéndices de Ángel Ma. Garibay K. México: IIH, UNAM, 2000.

Prescott, William H. "Diálogo de Oviedo con Don Thoan Cano, sacado de la Historia de las Indias Ms., Lib. xxxiII, cap. XLIv". En Historia de la conquista de México. Tomo II, trad. J. Navarro. París: Librería de Ch. Bouret, 1877, 365-374.

Relación de Zempoala y su partido en Tlalocan, vol. 3, 1949, $29-41$. SAHAGún, fray Bernardino de. Florentine Codex. General History of the Things of New Spain, Fray Bernardino de Sahagun. Libs. 2, 4, 6, 8. Traducido del náhuatl al inglés, con notas e ilustraciones por Charles E. Dibble y Arthur J. O. Anderson. Santa Fe: The School of American Research and The University of UTAH, 1950-1982.

. Códice Florentino. Vol. 2. México: Secretaría de Gobernación, 1979.

. Historia general de las cosas de Nueva España. Tomos I, II. Estudio introductorio, paleografía, glosario y notas de Alfredo López Austin y Josefina García Quintana. México: Conaculta, Colección Cien de México, 2002.

Serna, Jacinto de la. Manual de ministros de indios para el conocimiento de sus idolatrias y extirpacion de ellas. En El alma encantada, Anales del Museo Nacional de México. Presentador Fernando Benítez. México: INI, FCE, 1987, 261-480.

Siméon, Remi. Diccionario de la lengua náhuatl o mexicana, trad. Josefina Oliva. México: Siglo XXI editores, 2002.

Torquemada, fray Juan de. Monarquia Indiana de los veinte y un 
libros rituales y monarquí indiana, con el origen y guerras de los indios occidentales, de sus poblazones, descubrimiento, conquista, conversión y otras cosas maravillosas de la mesma tierra. Serie de historiadores y cronistas de Indias 5. Tomos I, IV. Edición preparada por el Seminario para el estudio de fuentes de tradición indígena, coord. Miguel León-Portilla. México: IIH, UNAM, 1975. Wimmer, Alexis. Diccionario de nábuatl clásico en CEN(Compendio Enciclopédico del Náhuatl). CD-ROM. México: INAH, 2004.

Zorita, Alonso de. Breve y sumaria relación de los señores de la Nueva España. Biblioteca del estudiante universitario. México: UnAM, 1963. 